\title{
Intact gastro-intestinal tract removal from pig carcasses in a novel Meat Factory Cell approach
}

Ole Alvseike ${ }^{1^{*}}\left(\mathbb{D}\right.$, Miguel Prieto $^{2,3}$, Per Håkon Bjørnstad ${ }^{1}$ and Alex Mason ${ }^{1,4}$

\begin{abstract}
Conventional automated slaughter lines for pigs are organised as disassembly lines with many specialised machines. High costs and capacities make them relevant only for large scale meat production. The ambition with the novel Meat Factory Cell (MFC) concept is to provide the meat industry with a robust and flexible automation platform that is also relevant for smaller scale production. The MFC process deviates radically from conventional processing of pig carcasses after singeing. In MFC, the limbs are removed first. Then the dorsal muscles along the spinal axis from tail to head are removed with the column and rind in one meat cut, followed by removal of the viscera. Finally, the cut ribs and belly are removed. Such approaches to automation in pig abattoirs and cutting plants are highly needed in smaller scale production, and they should produce meat and offal as hygienically as conventional factories. This case study reports the evisceration of 37 pigs in 9 trials performed in 2019. Several approaches were tested with a prototype carcass holding unit. Evisceration could be undertaken without the need to cut through the gastrointestinal tract from tongue to rectum, reducing the probability of accidental faecal contamination of pork carcasses from the gut content. The Meat Factory Cell procedure is an advance towards automated evisceration of pig carcasses which is both simple and hygienic. The traditional separation of internal organs into a pluck set and a set of stomach and bowels was more prone to leakages.
\end{abstract}

Keywords: Evisceration, Meat inspection, Pork, Slaughter hygiene

\section{Findings}

The Meat Factory Cell (MFC) approach for pig slaughter and primary cutting has recently been suggested and described [1,2]. MFC applies three principal changes to conventional meat production and processing:

1. Work partly organised in cell stations instead of lines.

2. Combine and merge elements of slaughter and meat primal cutting.

*Correspondence: ole.alvseike@animalia.no

${ }^{1}$ Animalia - Norwegian Meat and Poultry Research Center, P.O. Box 396 Økern, 0513 Oslo, Norway

Full list of author information is available at the end of the article
3. "Disassemble" the carcass from outside-in, without removal of internal organs before removal of most primary cuts.

Alternative processes should at least be as hygienic as traditional slaughter and cutting. Improved hygiene is expected from the MFC concept as the meaty limbs, neck and loin are removed first. These primary cuts are not subject to faecal contamination from intestinal content. The MFC process results in seven cuts; Four limbs, the saddle including head and tail, the viscera including pluck, stomach and intestines, and a cut comprised of ribs and belly, i.e. the belly-cut. Also, from a meat inspection point of view, detection of lesions and abnormalities should at least be as sensitive as in traditional procedures [2].

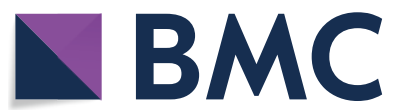

(c) The Author(s) 2020. This article is licensed under a Creative Commons Attribution 4.0 International License, which permits use, sharing, adaptation, distribution and reproduction in any medium or format, as long as you give appropriate credit to the original author(s) and the source, provide a link to the Creative Commons licence, and indicate if changes were made. The images or other third party material in this article are included in the article's Creative Commons licence, unless indicated otherwise in a credit line to the material. If material is not included in the article's Creative Commons licence and your intended use is not permitted by statutory regulation or exceeds the permitted use, you will need to obtain permission directly from the copyright holder. To view a copy of this licence, visit http://creativeco mmons.org/licenses/by/4.0/. The Creative Commons Public Domain Dedication waiver (http://creativecommons.org/publicdomain/ zero/1.0/) applies to the data made available in this article, unless otherwise stated in a credit line to the data. 
Avoiding bacterial contamination of carcasses and meat is the most important hygienic challenge in meat industry. Evisceration carries a high probability of carcass contamination due to knife cuts and perforations resulting in leakage of the intestinal content. Good Hygiene Practise for evisceration includes ensuring that the probability of perforating the viscera, alimentary tract, uterus, urinary bladder, and gall bladder is minimised during separation cuts [3]. In addition, and regardless of accidental knife perforations, the two ends of the gastrointestinal tract are potential sources of carcass contamination [3]. In conventional slaughter lines, the pig carcasses are suspended by the hind legs. This allows use "bagging", a technique in which a plastic bag is used to seal the rectum after circum-anal incision [4]. The sealed rectum is then pulled through the transected Os pubis and removed together with the intestines.

The oral cavity, with the tongue and palatine tonsils, is known to harbour a high bacterial load, including zoonotic bacteria [5]. It has been considered optimal to avoid cutting into tonsils while removal of the pluck, and "stunning, bleeding, skinning, evisceration and other dressing must be carried out without undue delay and in a manner that avoids contaminating the meat. In particular, the trachea and oesophagus must remain intact during bleeding" [6]. However, recently an alternative approach leaving the tongue with tonsils, pharynx, larynx and part of trachea and oesophagus intact on the head produced the lowest contamination levels on pig carcasses [7].

According to the Regulation EC No 853/2004, Annex III, Section I, Chapter IV, point 7 c, "measures must be taken to prevent the spillage of digestive tract content during and after evisceration" [6]. It was hypothesised that the MFC approach could possibly allow the alimentary tract to be removed intact [2]. If successful, this approach would significantly improve hygiene and reduce zoonotic risks associated with pork. We are not aware that removal of the entire gastrointestinal tract has been reported before and so, probably for the first time, fulfilling this intention of the EU legislation.

The aim of this study was to test in practice and describe evisceration of gastro-intestinal tract at slaughter of pigs in the MFC approach in a manner feasible for automation.

Figure 1 shows the schematic cutting pattern applied in the trials. Five pigs where processed in three iterative trials conducted at a workshop on a farm in Norway from April to June 2019. After three trials (5 pigs), it was concluded how the carcass should be fixed, tools of choice, cutting trajectories and a more detailed procedure. Then, 32 crossbred white pigs, castrates and

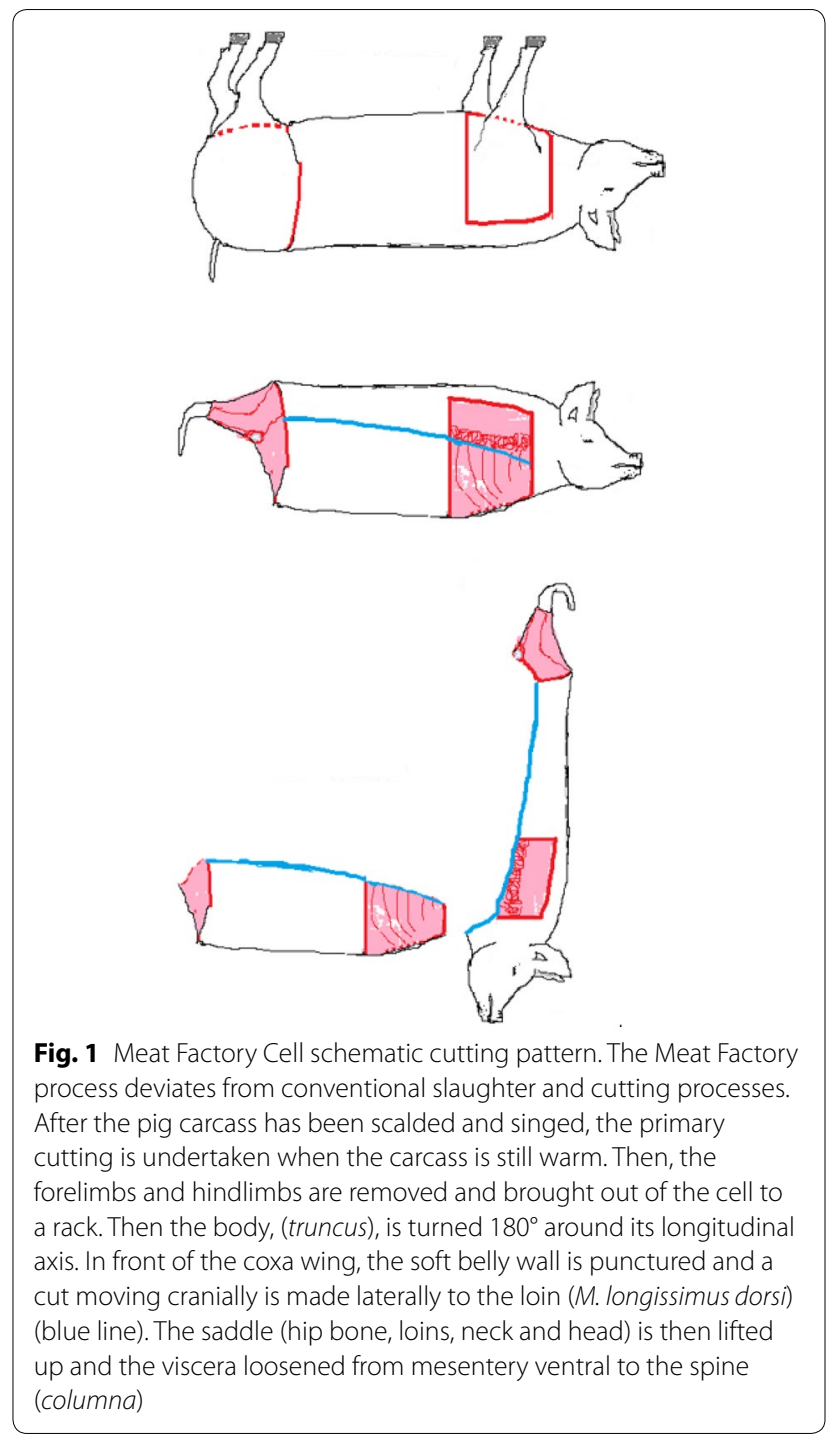

females, with approximately $110 \mathrm{~kg}$ live weight were slaughtered over a 6-week period in an abattoir, in total 37 pigs.

The first five pigs were stunned with a captive bolt pistol and bled indoors at the piggery, transported with tractor to the scalding bath, scalded in a hot water bath (approx. $65^{\circ} \mathrm{C}$ ), scraped manually and singed with a gas burner.

The pigs were bagged and brought to the MFC after singeing and mounted to a prototype Carcass Holding Unit (CHU) (Tronrud Engineering AS, Hønefoss, Norway) designed for the MFC approach. The system was designed to accept a carcass from the hanging position (e.g. vertically from a rail) and present horizontally for cutting. The carcass could also be rotated 180 degreescutting began with the belly-cut facing upwards and 
proceeded to belly-cut facing downwards once all limbs had been removed. The carcass was fixed at the head (snout and eye sockets) as well as at the rear. A serrated clamp fixed Os sacrum after removal of the hind limbs. Vacuum suction cups $(n=5)$ held the back of the pig to enable initial fixation, stretching during rib sawing, and lifting and removal of the back prior to internal organ removal (Fig. 2).

The slaughter and cutting process was developed iteratively in collaboration with veterinarians, butchers and engineers. Limbs were removed with a knife, and the entire back from hip to neck lifted away as shown in Fig. 2. Then the thoracic and abdominal viscera were exposed, resting on the ribs and sides as shown in Fig. 2. The butcher freed the trachea and oesophagus towards the larynx. With two lateral cuts along the mandibles, avoiding the tonsils, and a transverse cut through the soft palate it was possible to remove the tongue as well as the pharynx with tonsils. While gripping firmly around trachea and oesophagus beneath larynx, the organs where pulled backwards.

Three alternative principal evisceration processes for the pluck were identified:

1. Removal of tongue, larynx, oesophagus, trachea, lungs and heart in one piece. This necessitates a cut through oesophagus close to the diaphragm.

2. Similar to 1, but without cutting the oesophagus. Instead, the diaphragm was loosened with a knife at the attachment to the thoracic and abdominal wall. The viscera were continuously pulled in the aboral direction, loosening mesenteries and normal adher-

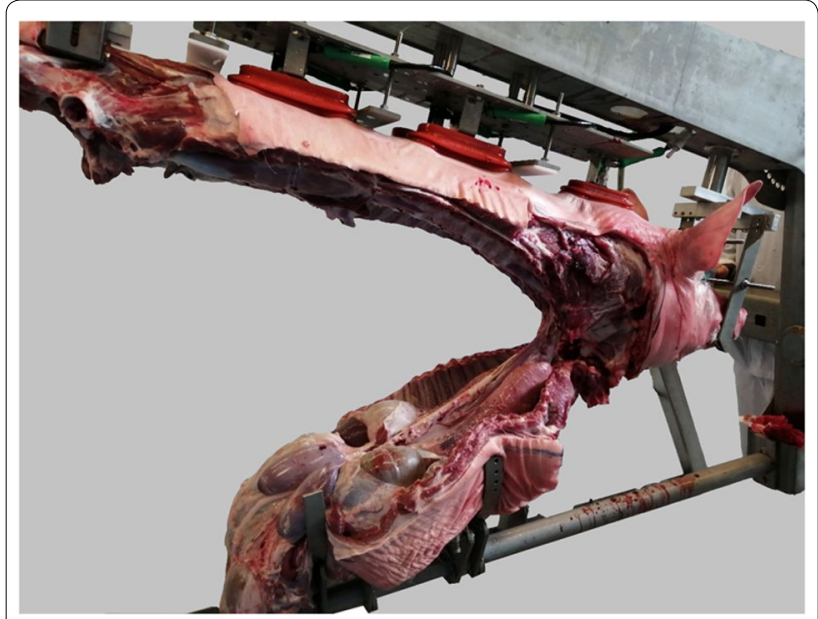

Fig. 2 The Meat Factory Cell's "Carcass Handling Unit". The limbs have been removed and the belly and ribs sawed approximately $12-15 \mathrm{~cm}$ from the spine. Then the truncus has been lifted up. Trachea, oesophagus with some soft tissue is available for the butcher ences with a knife until they detached from the caudal end of the belly-cut. The easiest operation was to include the peritoneum and underlying fats (flare fat) in the removed viscera. As a result, the entire gastrointestinal tract and other viscera (tongue, pharynx, tonsils, oesophagus, stomach, liver, gall bladder, mesenteries, flare fat, urinary bladder, genitalia and intestines from duodenum to anus) were removed in one piece. Heart, lungs and spleen followed the set, while the kidneys could either follow or be left on the back to ease meat inspection. The entire set of viscera is shown in Fig. 3.

3. Similar to 2, but a conventional set of plucks was produced by transecting oesophagus at the entrance to the stomach. The resulting pluck consisted of tongue, trachea, lungs, heart, diaphragm and liver. The stomach and intestines then glided off or could be physically torn off including the flare fat.

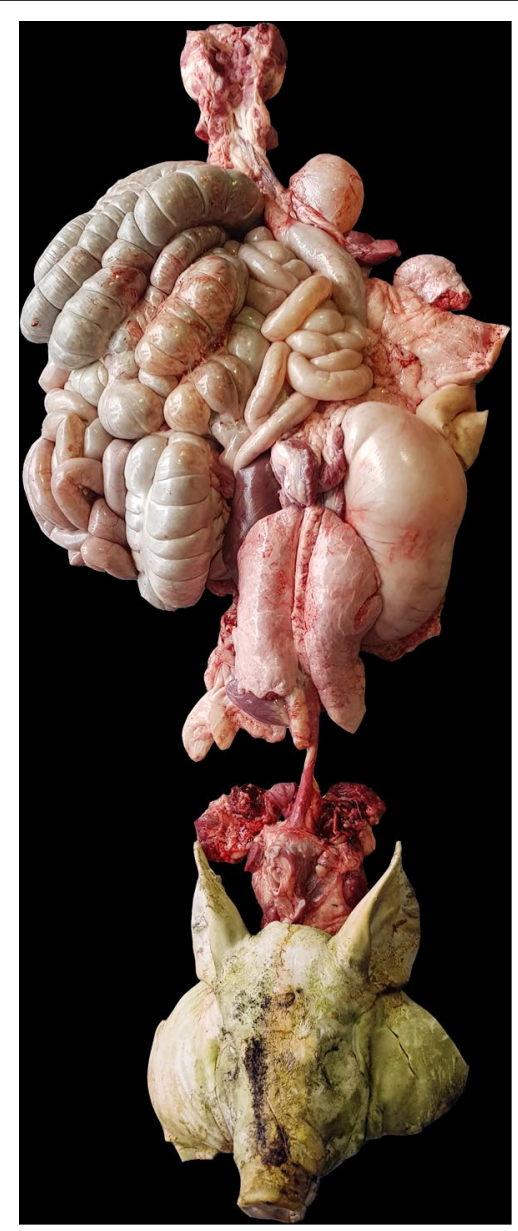

Fig. 3 Evisceration in a Meat Factory Cell. The picture shows the gastrointestinal tract intact in one piece. Here, the kidneys were left on the back part. The organs were photographed lying on the floor 
Figure 2 shows that trachea and oesophagus are being openly exposed. The recently described alternative pluck removal [7] was not explored but would probably further simplify robotic operations within the cell.

Our study reports the methodology and experiences with alternative evisceration methods applied in MFC pilots. Most interestingly, the alternative procedure (2) allowed the butcher to remove the gastrointestinal tract intact in one piece. In fact, the presentation of the carcass made it a relatively easy technique for the butcher. The traditional separation of internal organs into a pluck set and a set of stomach and bowels was more cumbersome with higher probability of ruptures and leakages.

From a veterinary hygienic perspective, we have not so far identified disadvantages with the MFC approach. The biggest challenge is that MFC does not fit with the wording of regulatory paragraphs, e.g. that the viscera should be removed as soon as possible [6]. In MFC, evisceration is almost the last operation, but the whole process is undertaken within 8-12 min in the present demo set-up.

Coincidentally, two pigs presented pathological changes. One had an umbilical hernia filled with greyish debris and turbid fluid. The orifice to the abdominal cavity was practically closed by fat tissues. The flare fat was easily removed, and local condemnation of affected tissue was hygienically undertaken. The second presented chronic fibrous adhesive peritonitis between liver, mesentery and stomach. The individual was also heavily infested with Ascaris suum. Again, the evisceration appeared simpler than if this carcass was presented on a conventional line. The evisceration could also be undertaken hygienically as the whole set could be removed before further examination.

The research group strives to provide the meat industry with a robust, flexible and scalable cognitive robotic platform [8]. The removal of an entire set of internal organs appeared feasible for an automated evisceration procedure because the robot may need only one gripping point (trachea) and one relatively simple operation, compared to delicate identification, gripping and removal of the pluck or specific internal organs.

MFC is more robust against downtime because an automated conventional line stops if a machine in the line is out of order. MFC is more flexible because the processing can adjust to varying sizes of animals without reducing the speed in neighbouring cells, or development and maintenance can be undertaken in one cell without interfering with the others. A factory can operate an optimal number of cells depending on day to day variation. Working from outside in, makes it possible to apply cheaper cognitive elements (sensors, cameras and artificial intelligence), e.g. 3D cameras to control movements and optimise cutting trajectories by artificial intelligence.
Alternatively, conventional automated lines apply many and expensive specialised machines with low flexibility, e.g. Danish Crown's plant in Horsens, Denmark [9]. Another example of an automation solution in cold meat cutting depends on control information obtained from expensive $\mathrm{x}$-ray systems that produce a static picture from one point in time before processing, not able to adapt to the configural changes when a carcass is processed warm [10].

However, from a meat technological perspective there are several pro and cons. The hams, with the present cutting trajectories, are leaving the hip bone attached to the spine and back part, resulting in a cut that, for example, deviates from the Spanish dry-cured ham raw material. On the positive side, meat producers could customise the cooling regimes for specific cuts and improved water binding effects of warm pre-salted trimmings.

A disadvantage was that the set of internal organs needs to be handled afterwards to separate parts and organs to present them for meat inspection. This was not studied as customised equipment needs to be constructed for these operations. It could also be a challenge to rip off the flare fat in an entire piece.

The two pigs with lesions became examples where the evisceration in case of pathology could be performed more hygienically with the MFC approach with reduced probability of accidental contamination of the carcass from ruptures.

In conclusion, Meat Factory Cell evisceration can be undertaken without the need to cut through the gastrointestinal tract. It is a novel procedure reducing the probability of accidental faecal contamination from gut content of pork carcasses, and we also think it will reduce the complexity of the evisceration procedure and therefore be suitable for automated evisceration.

\section{Abbreviations}

CHU: Carcass Holding Unit; MFC: Meat Factory Cell.

\section{Acknowledgements}

Kristof Takacs, Obuda University made the photo used in Fig. 2. The editing was performed by Kaia Seweriin, Animalia.

\section{Prior publication}

Data have not been published previously.

\section{Authors' contributions}

OAA suggested the concept that developed into MFC and was central in applying for and establishing the credited projects. He contributed to the specification of the $\mathrm{CHU}$ and planning of the trials, including the iterative development of the slaughter and cutting process. OAA drafted and finished the manuscript with input from co-authors. He also made the schematic figure. Images were selected together with AM. MP contributed with structuring of the manuscript and critical input to the text with emphasis on the hygiene and meat inspection aspects. PHB contributed to the specification of the $\mathrm{CHU}$ and planning of the trials, including the iterative development of the slaughter and cutting process. PHB has provided input to the manuscript. AM was central in applying for and establishing the credited projects MeaTable 
and RoBUTCHER. He contributed to the specification of the $\mathrm{CHU}$ and planning of the trials, including the iterative development of the slaughter and cutting process. AM has provided input to the manuscript and proof-reading. Pictures were selected together with OAA. All authors have read and approved the final manuscript.

\section{Funding}

This study was a part of the MeaTable (Grant ID 281234) and Meat 2.0 (Grant ID 256266) project and was supported by the Norwegian Research Council, grant no. 244493/E50. MeaTable was co-funded by Nortura SA, RobotNorge AS, Tronrud Engineering AS and Animalia AS. Meat 2.0 was co-funded by Nortura SA, and also from the European Union's Horizon 2020 research and innovation program under Grant agreement No 871631 (RoBUTCHER).

\section{Availability of data and materials}

Data sharing not applicable to this article as no datasets were generated or analysed during the current study.

\section{Ethics approval and consent to participate}

This study did not require official or institutional ethical approval. The animals were handled according to high ethical standards and national legislation.

\section{Consent for publication}

Not applicable.

\section{Competing interests}

The authors declare that they have no competing interests.

\section{Author details}

${ }^{1}$ Animalia - Norwegian Meat and Poultry Research Center, P.O. Box 396 Økern, 0513 Oslo, Norway. ${ }^{2}$ Department of Hygiene and Technology of Foods, Veterinary Faculty, University of León, 24071 León, Spain. ${ }^{3}$ Institute of Food Science and Technology, University of León, 24071 León, Spain. ${ }^{4}$ Faculty of Science and Technology, Norwegian University of Life Sciences, 1430 Ås, Norway.

Received: 21 April 2020 Accepted: 24 August 2020

Published online: 31 August 2020

\section{References}

1. Alvseike O, Sverdvik H, O'Farrell M, Berg P. Meat factory cell—a concept for the future? In 63rd International Congress of Meat Science and Technology; 2017. pp. 494-5.

2. Alvseike O, Prieto M, Torkveen K, Ruud C, Nesbakken T. Meat inspection and hygiene in a Meat Factory Cell - an alternative concept. Food Control. 2018;90:32-9.

3. Nesbakken T, Nerbrink E, Røtterud O-J, Borch E. Reduction of Yersinia enterocolitica and Listeria spp. on pig carcasses by enclosure of the rectum during slaughter. Int J Food Microbiol. 1994;23:197-208.

4. Røssvoll E, Røtterud O-J, Hauge SJ, Alvseike O. A comparison of two evisceration methods on hygienic quality in the pelvic area of sheep carcasses. Meat Sci. 2017;137:134-8.

5. Borch E, Nesbakken T, Christensen H. Hazard identification in swine slaughter with respect to foodborne bacteria. Int J Food Microbiol. 1996;30:9-25.

6. Anon. Regulation (EC) No. 853/2004 of the European Parliament and of the Council of 29 April 2004 laying down specific hygiene rules for food of animal origin. Official Journal ofthe European Union, $\mathrm{L}$ 226(25/06/2004), 22-82.

7. Biasino W, De Zutter L, Woolard J, Mattheus W, Bertrand S, Uyttendaele M, et al. Reduced contamination of pig carcasses using an alternative pluck set removal procedure during slaughter. Meat Sci. 2018;145:23-30.

8. RoBUTCHER-A Robust, Flexible and Scalable Cognitive Robotics Platform, Norwegian University of Life Sciences, Ås, Norway. 2020. https://robut cher.eu/. Accessed 30 June 2020.

9. Nielsen JU, Madsen NT, Clarke R. Automation in the meat industry, Slaughter Line Operation. In: Dikeman M, Devine C, editors. Encycl, vol. 1., Meat SciAcademic: Amsterdam; 2014. p. 43-52.

10. Clarke R, Nielsen JU, Madsen NT. Automation in the meat industry, cutting and deboning. In: Dikeman M, Devine C, editors. EncyclMeat Sci, vol. 1. Academic: Amsterdam; 2014. p. 43-52.

\section{Publisher's Note}

Springer Nature remains neutral with regard to jurisdictional claims in published maps and institutional affiliations.
Ready to submit your research? Choose BMC and benefit from:

- fast, convenient online submission

- thorough peer review by experienced researchers in your field

- rapid publication on acceptance

- support for research data, including large and complex data types

- gold Open Access which fosters wider collaboration and increased citations

- maximum visibility for your research: over 100M website views per year

At BMC, research is always in progress.

Learn more biomedcentral.com/submissions 